\section{Merger terminated}

The merger between Genzyme General (Cambridge, MA) and Cell Genesys (Foster City, CA) has been scrapped after shares of a Cell Genesys subsidiary became more valuable than the cash offer from Genzyme. In November 1999, Genzyme was set to acquire Cell Genesys for a net cost of $\$ 160$ million (Nat. Biotechnol. 17, 151, 1999). The purchase would have included Cell Genesys' 19\% share in Abgenix (Fremont, CA), a company developing human monoclonal antibody therapies. But in late December, the Cell Genesys board of directors recommended against the merger after the value of its equity share in Abgenix jumped by about $\$ 240$ million to more than $\$ 350$ million as Abgenix's share price tripled to $\$ 120$ in the wake of several important deals. These include aquisition of full rights of XenoMouse technology from Japan Tobacco and a five-year pact with CuraGen (New Haven, CT) to develop cancer drugs using the technology. Cell Genesys officials say they have no plans for other mergers, but do intend to sell the firm's share in Abgenix over time to raise capital for research projects and product acquisition in the areas of cancer and cardiovascular disease. Cell Genesys will pay Genzyme a $\$ 15$ million termination fee.

\section{Rapigene bargain buy for Qiagen}

In January, Qiagen (Venlo Park, The Netherlands) acquired the genomic analysis company Rapigene from Celltech Chiroscience (Slough, UK). The buyout comes as the fallout from the merger of Celltech (Slough, UK), Chiroscience (Cambridge, UK), and Medeva (London) (Nat. Biotechnol.18, 7, 2000). Rapigene represents the rump of the genomics operations that Chiroscience acquired when it bought Darwin Molecular (Bothell, WA) in November 1996. Chiroscience paid \$120 million in shares for Darwin at a time when the value of UK biotechnology stock prices were grossly inflated compared with those in the US. Qiagen is paying \$12 million in shares for a 15-person Rapigene.

\section{Amgen lists on Easdaq}

The next biotechnology company to be traded on the Brussels-based pan-European stock market, Easdaq, will be Amgen (Thousand Oaks, CA). The biopharmaceutical specialist is among 10 Nasdaq stocks (others include Microsoft, Intel, Dell Computer, Yahoo, and Amazon.com) that will be traded on Easdaq's new dual trading facility.

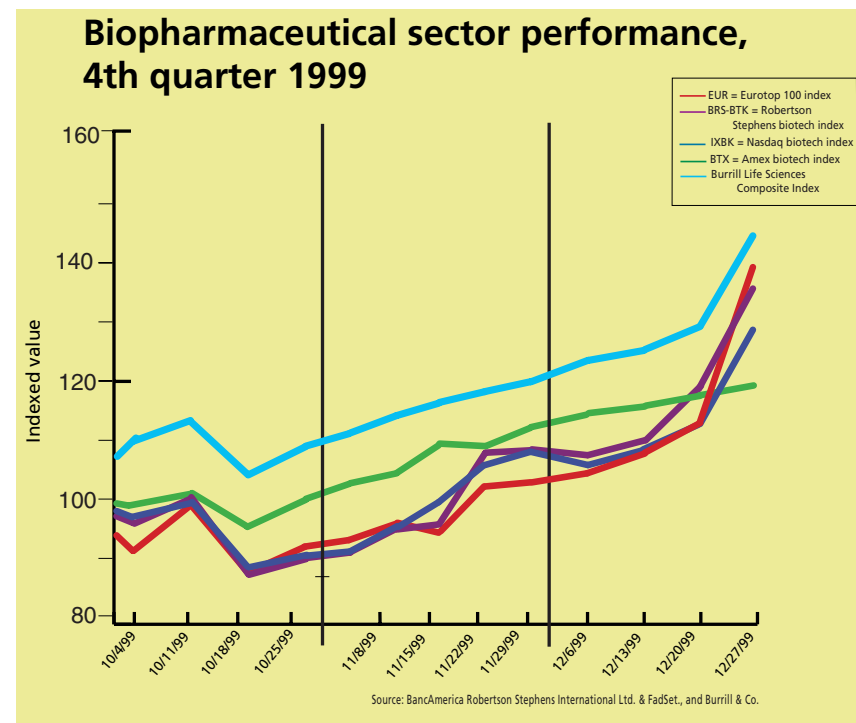

Initial public offerings, 4th quarter 1999

The fourth quarter saw 7 IPOs, raising a total of $\$ 432.2$ million.

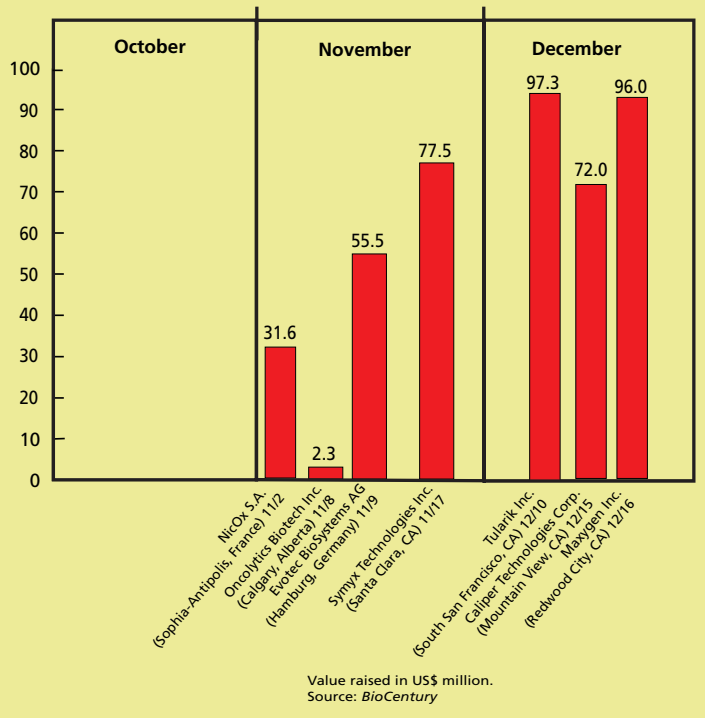

\section{\$100 million pesticide deal}

Bayer (Leverkusen, Germany) has established a joint venture with genomics company Exelixis Pharmaceuticals (S. San Francisco, CA) to develop new generations of insecticides and nematicides. The new venture, to be called GenOptera and based in S. San Francisco, is a continuation and expansion of a collaboration that began in mid-1998 to identify novel screening targets for the development of new crop protection agents. Exelixis employs invertebrate genetics, genomics, and computational biology to identify, prioritize, and validate targets in insects and nematodes, which could lead to development of pesticides that are safer and more effective than chemical pesticides currently in use. Under the agreement-one of the largest in plant biotechnology-Exelixis will receive $\$ 80$ million in research support over eight years and $\$ 20$ million in return for granting licensing rights to Bayer and GenOptera for technologies including targets and assays, as well as milestones and royalty payments.

\section{India joins rice project}

India has joined the 11-nation international rice genome sequencing project led by Japan's Ministry of Agriculture, Forestry, and Fisheries. At a recent Indian science congress, science minister Murli Manohar
Joshi said the project would help Indian scientists "produce genetically modified rice plants having desirable traits like high yield, resistance against pests and diseases, and improved adaptability to drought." Indian scientists will sequence chromosome 11 of the rice genome-a 5-year, $\$ 13.7$ million effort that the World Bank has in principle agreed to fund with a loan, according to Manju Sharma, Indian Department of Biotechnology secretary. Although the Indian program will be formally launched in April, steps have already been taken to acquire six high-speed automatic DNA sequencers and begin training. With rice accounting for $45 \%$ of India's cereal production, says Sharma, "this is an area where we cannot lag behind." 